\title{
Impact of Front Line Demonstration on Yield Enhancement of Transplanted Rice in Seoni District of Madhya Pradesh
}

\author{
Khenendra Kumar Deshmukh* and Sita Ram Dhuware
}

Jawaharlal Nehru Krishi Vishwa Vidyalaya, Krishi Vigyan Kendra, Seoni, (M.P.), India

*Corresponding author

\section{A B S T R A C T}

Keywords

Front line demonstration, Yield enhancement, Technology gap, Extension gap

Article Info

Accepted:

26 January 2021

Available Online:

10 February 2021
The study was carried out by Krishi Vigyan Kendra, Seoni during Kharif from 2013-14 to 2016-17. Total 40 demonstrations were conducted on rice in 16 ha. by the active participation of the farmers with objective of improved technologies of rice production. The improved technologies consist improved high yielding variety, Soil test value based nutrient application and integrated diseases and pest management etc. The average four year dada observed that an average yield of demonstrated plot was $3763 \mathrm{~kg}$. over control (3413 kg/ha.) with an additional yield of $350 \mathrm{~kg} / \mathrm{ha}$. and the increase average rice productivity by 10.25 percent. The average extension gap technology gap, extension gap and technology index were $350 \mathrm{~kg} / \mathrm{ha}$., $236 \mathrm{~kg} / \mathrm{ha}$. and $5.9 \%$ respectively.

\section{Introduction}

Many agricultural technologies have been developed by researchers worldwide, but these technologies have not been adopted by farmers in many instances. Many reasons, including poor communication of results along with high costs and other socioeconomic constraints have been put forward for poor uptake resulting in a yield gap at local, regional and global levels. One way that has been shown to improve adoption of technologies in the involvement at farmers throughout the development process, from the initial inclusion and testing of treatments through to experimentation by farmers themselves. Technology transfer refers to the spread at new ideas from originating sources to ultimate users (Prasad et al., 1987). Front line demonstration is one of the most powerful tools for transfer of technology.

Rice is the important staple foods which cover 65 percent of the population in india. It is the largest consumed calorie source among the food grains. India is the second largest producer of rice in the world next to China. In M.P. rice is grown in the area of about 27.94 Lakh ha. with production of 78.58 lakh tonnes and productivity $2813 \mathrm{~kg} / \mathrm{ha}$. In seoni district 167043 ha. area under rice cultivation in 2018-19 with 368049 Mt. Production and 
productivity of $2204 \mathrm{~kg} / \mathrm{ha}$ (Agricultural statics, 2018-19).

It indicates that the productivity of rice in seoni district is comparatively low, primarily due to lack knowledge of improved production technologies. The productivity of rice could be increased by adopting recommended scientific and sustainable management production practices (Singh et al 2017). Front line demonstration is the new concept at field demonstration with main objective to demonstrate newly released variety with improved practices technologies and its management practices at farmers field under different agro climatic regions of the country with varying farming situations. Productivity of rice per unit area can be increased by adopting feasible, scientific and sustainable management practices by selecting a suitable variety. With this in view front line demonstration held at farmers field, in a systemic manner to convince them to about the potential of improved production technologies to enhance yield of rice.

\section{Materials and Methods}

The study was carried out by Krishi Vigyan Kendra Seoni Jawaharlal Nehru Krishi Vishwavidhyalaya, during Kharif season from 2013-14 to 2016-17 four consecutive years in the farmers field of five adopted villages of seoni district. During this four year of study in area of 16 ha. was covered with plot size 0.4 ha. under front line demonstration with active participation of 40 farmers. Before conducting frontline demonstration a list of farmers were prepared from group meeting and specific skill training was given to the selected farmers regarding package of paractices of rice.

The soils of demonstration sites were loamy in texture with $\mathrm{pH}$ range between 5.9 and 6.8. The available nitrogen, phosphorus and potassium varied between 180-260, 15-24, 280-330 kg/ha. respectively, However the soils were deficient in available zinc. In demonstration plots use of quality seeds of improved variety, timely weeding, STV based plant nutrient application, need based IPM and IDM were emphasized and comparison has been made with the farmers practice (local check). The necessary steps for the selection of sites and farmers, layout of demonstration etc., were followed as suggest by choudhary (1999). The tradition practices were maintained in case of local check. The data output were collected from both FLD plots as well as local check and finally the extension gap, technological gap, technological index along with the benefit cost ratio were calculated using the formula as suggested buy samui et al., (2020).

Extension gap $=$ Demonstration Yield Farmers Yield

Technology gap $=$ Potential Yield Demonstration Yield

Technology Index $(\%)=[$ Technology gap $/$ Potential yield] x 100

\section{Results and Discussion}

A comparison of the productivity level between front line demonstrations and local checks is shown in table-1. It is evident from results that under the demonstration plot, performance of rice yield was sustainable higher than that in local check in all the years of the study (2013 -14 to 2016-17).

Average four year data observed that an average yield of demonstrated plots was 3763 $\mathrm{kg} / \mathrm{ha}$. over control (3413 kg/ha.) with an additional yield at $350 \mathrm{~kg} / \mathrm{ha}$ and the increase average rice productivity by 10.25 per cent. Small fluctuations in yield observed over the years were mainly on account of variation in 
rainfall, transplanting time and pest and disease attack. Mukharjee (2003) had reported that the innovative intervention may have superior implications in enhancing productivity. Similar results were also reported by others namely mishra et al., (2009), Tiwari et al., (2003), Tiwari and
Saxena (2001) in different crops. The data indicated that the positive effect of front line demonstration over the existing practices towards increasing the yield of rice in seoni district of Madhya Pradesh. B:C ratio was recorded to be higher under demonstration than the local check during all the four years.

Table.1 Performance of front line demonstrations on yield and per cent increase of rice

\begin{tabular}{|c|c|c|c|c|c|c|}
\hline \multirow{2}{*}{ Year } & Area & No. of & \multicolumn{3}{|c|}{ Seed Yield (q/ha) } & \% Increase \\
& & Farmers & Potential & Demonstration & Control & over control \\
\hline $\mathbf{2 0 1 3 - 1 4}$ & 4.8 & 12 & 40 & 37.8 & 34.40 & 11.17 \\
\hline $\mathbf{2 0 1 4 - 1 5}$ & 4.0 & 10 & 40 & 38.50 & 34.80 & 10.63 \\
\hline $\mathbf{2 0 1 5 - 1 6}$ & 4.0 & 10 & 40 & 35.85 & 32.25 & 11.16 \\
\hline $\mathbf{2 0 1 6 - 1 7}$ & 4.0 & 10 & 40 & 38.0 & 35.50 & 8.16 \\
\hline & & Average & 37.63 & 34.13 & 10.28 \\
\hline
\end{tabular}

Table.2 Performance of front line demonstrations on Technology gap, Extension gap Technology index and $\mathrm{B}$ : $\mathrm{C}$ ratio of rice

\begin{tabular}{|c|c|c|c|c|c|}
\hline Year & Technology & Extension gap & Technology & \multicolumn{2}{|c|}{ B:C Ratio } \\
\cline { 5 - 6 } & gap (q/ha.) & (q/ha.) & index $\%$ & Demonstration & Local check \\
\hline $\mathbf{2 0 1 3 - 1 4}$ & 2.2 & 3.80 & 5,5 & 2.05 & 1.92 \\
\hline $\mathbf{2 0 1 4 - 1 5}$ & 1.50 & 3.70 & 3.75 & 2.41 & 2.20 \\
\hline $\mathbf{2 0 1 5 - 1 6}$ & 4.15 & 3.60 & 10.37 & 2.32 & 2.19 \\
\hline $\mathbf{2 0 1 6 - 1 7}$ & 1.60 & 2.90 & 4.0 & 2.47 & 2.25 \\
\hline Average & 2.36 & 3.5 & 5.90 & 2.31 & 2.10 \\
\hline
\end{tabular}

Yield in frontline demonstration and potential yield was compared for estimating yield gaps. These gaps were further categorized as technology and extension gaps. Technology gap indicates a gap in demonstration yield over the potential yield and average technology gap was $236 \mathrm{~kg}$. The technology gap observed may be attributed to dissimilarities in soil fertility, rainfall and other vagarics of weather in the demonstration areas.

The extension gap ranging between 290 to $380 \mathrm{~kg} / \mathrm{ha}$. (Table 2) During the period of study emphasis the need to educate the farmers through various technologies for adoption of improved agricultural production reverse the trend of wide extension gap.

The technological index revealed that the feasibility of the demonstration technology. As such variation in technology index (3.75 to 10.37) during the study period in certain area may be attributed to dissimilarity in the soil fertility gradient, pest-disease infestation and poor weather conditions. This finding corroborates results at Lal et al., 2016, Meena et al., 2016 and Poonia et al., 2017.

The results obtained in present study it can be concluded that use of improved method of rice cultivation can reduced the technology 
gap to a considerable extent thus leading to increase productivity at rice in the district. Extension gap ranged between 290 to 380 $\mathrm{kg} / \mathrm{ha}$. which emphasis the need to educate the farmers through various means like farmers training, method demonstrations, frontline demonstrations etc. Technology index which shows that feasibility of the technology demonstrated has depicted good performance of the intervention.

\section{References}

Agricultural statistics, 2018-19. Farmers welfare and agriculture department, Madhya Pradesh

Chaudhary B.N. 1999. Krishi Vigyan Kendra - A guide for KVK managers. Division of Agricultural extension, ICAR, PP 7378.

Lal, G., Mehta, R.S., Meena, N. K. and Choudhary, M.L. 2016. Impact of frontline demonstration on yield enhancement of coriander: a case study in TSP area of Pratapgarh. E News Letter, ICAR-Research centre on seed spices, 8(3): 5-6.

Meena, K.C., Singh, D. K., Gupta, I.N., Singh B., Meena S. S. 2016. Popularization of coriander production technologies through front line demonstrations in Hadauti region of Rajasthan. Int. J. Seed Spices, 6 (2): 24-29.

Mishra D.K. Paliwal D.K. tailor R.S. Deshwal, A.K. 2009. Impact of frontline demonstration on yield enhancement of potation Indian
Research Journal of Extension Education 9(3) 26-28.

Mukherjee: N. 2003. Participatory learning and action. New Delhi concept publishing company.

Poonia, M. K., Manendra Singh, B. L. Dhaka, R. K. Bairwa and Bheru lal Kumhar, 2017. Impact of front line demonstration on the yield and economics of coriander in Kota district of Rajasthan, India. Int. J. Curr. Microbio. App. Sci., 6(3): 2344-2348.

Prasad C, Choudhary BN, Nayar BB 1987. First line transfer of technology project New Delhi ICAR.

Saamui, S.K. Maitra, s, Roy D.K., Mandal, A.K. and Saha, D. 2000. Evaluation of frontline demonstration on groundnut. J. Indian soc. cuastal Agric. Res., 18 (2) 180-183

Singh, Jagmohan, Raminder Kaur Hundal and B.S. Dhillon (2017). Comparison for yield potential of chickpea in front line demonstrations and farmers practices in the Amritsar District at Punjab. Current Agriculture Research Journal, 5 (2), 239-243.

Tiwari, R.B. Singh V, Parihar, P. 2003. Role of frontline demonstration in transfer of gram production technology. Maharashtra Journal of Extension Education, 22 (3):19.

Tiwari K.B., Saxena, A. 2001. Economic analysis at FLD of oilseeds in Chindwara. Bhartiya Krishi Anusandhan Patrika, 13 (3 and 4): 185189.

\section{How to cite this article:}

Khenendra Kumar Deshmukh and Sita Ram Dhuware. 2021. Impact of Front Line Demonstration on Yield Enhancement of Transplanted Rice in Seoni District of Madhya Pradesh. Int.J.Curr.Microbiol.App.Sci. 10(02): 3369-3372. doi: https://doi.org/10.20546/ijcmas.2021.1002.370 